\title{
DỨcin
}

Technological University Dublin ARROW@TU Dublin

\section{Outstanding Reviewers for Analyst in 2019}

\author{
Royal Society of Chemistry
}

Follow this and additional works at: https://arrow.tudublin.ie/focasart

Part of the Chemistry Commons

\section{Recommended Citation}

Royal Society of Chemistry, "Outstanding Reviewers for Analyst in 2019" (2020). Articles. 1.

https://arrow.tudublin.ie/focasart/1

This Article is brought to you for free and open access by the Focas Collaborations at ARROW@TU Dublin. It has been accepted for inclusion in Articles by an authorized administrator of ARROW@TU Dublin. For more information, please contact arrow.admin@tudublin.ie, aisling.coyne@tudublin.ie, gerard.connolly@tudublin.ie.

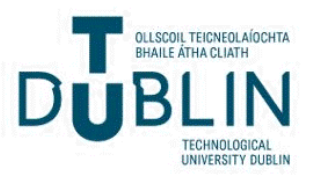




\section{Analyst}

\section{Outstanding Reviewers for Analyst in 2019}

Cite this: Analyst, 2020, 145, 4068

DOI: 10.1039/d0an90052d

rsc.li/analyst

We would like to take this opportunity to thank all of Analyst's reviewers, and in particular highlight the Outstanding Reviewers for the journal in 2019, as selected by the editorial team for their significant contribution to Analyst. We announce our Outstanding Reviewers annually and each receives a certificate to give recognition for their contribution. The reviewers have been chosen based on the number, timeliness and quality of the reports completed over the last 12 months.

Professor Hugh Byrne Dublin Institute of Technology ORCID: 0000-0002-1735-8610

Professor Lingxin Chen Chinese Academy of Sciences ORCID: 0000-0002-3764-3515
Dr Yu-Chung Chang Washington State University ORCID: 0000-0002-2764-7010

Professor Jeremy Driskell Illinois State University ORCID: 0000-0001-5082-898X

Professor Ning Gan Ningbo University ORCID: 0000-0001-9772-2437

Professor Hideaki Hisamoto Osaka Prefecture University ORCID: 0000-0003-1067-4116

Dr Juewen Liu University of Waterloo ORCID: 0000-0001-5918-9336

\author{
Professor Francis Martin \\ University of Central Lancashire \\ ORCID: 0000-0001-8562-4944 \\ Dr Muhammad Shiddiky \\ Griffith University \\ ORCID: 0000-0003-4526-4109 \\ Dr Chun-yang Zhang \\ Shandong Normal University \\ ORCID: 0000-0002-8010-1981
}

We would also like to thank the Analyst Editorial Board and Advisory Board and the analytical chemistry community for their continued support of the journal, as authors, reviewers and readers.

\footnotetext{
Duncan Graham, Editor-in-Chief Philippa Ross, Executive Editor Rebecca Garton, Editorial Production Manager
} 